as has been shown in Carmarthenshire and by experiment in Devon and Pembrokeshire. Various humane traps and snares were shown together with apparatus for cyanide fumigation, but the latter was put forward as by far the best method for the painless and effective control of the rabbit. A bookstall was provided by the Cathedral Bookstall, Canterbury, and departments of the College provided many of the specimens and the apparatus. Messrs. Flatters and Garnett, Ltd., W. Watson and Co., E. Gerrard and Co., Ltd., Thomas Murby and Co. provided material, and the Folkestone Museum lent some cases and specimens.

\section{Physics in 1936}

THE rapid advances now being made in our knowledge of the physical properties of matter have made it desirable that progress reports should be published at frequent intervals; three such reports have been issued by the Physical Society, and a number have appeared from time to time in the issues of the Physikalische Zeitschrift, the latest being on nuclear physies by Profs. S. Flügge and A. Krebs, which occupies twenty-four pages of the issue of January 1. The Physics Forum in the issue of the Review of Scientific Instruments of January occupies twelve pages devoted entirely to a review of some of the most noteworthy advances, by Prof. T. H. Osgood of the University of Toledo, Ohio. It deals with the collisions of slow and fast neutrons with atomic nuclei and the knowledge of the effective cross-sections of nuclei which has been derived from them; with the scattering of one type of nuclear particle by another and the applicability of gravitational and electrical inverse square laws of action of one particle on another; the changes of mass when atoms are built up of their constituent parts; the recent removal of doubts as to the validity of the momentum explanation of the Compton effect; the frequent transformations from matter to radiation and back again which take place in the path of a cosmic ray, which make complete investigation difficult ; the discovery that the oscillations of the atoms in a crystal lattice are not isotropic and the question whether supraconductivity in metals, which is suppressed instantly by a magnetic field and more slowly by a rise of temperature, is due to a surface or a volume effect. Prof. Osgood also touches on the increased accuracy of newspaper articles on scientific subjects and on "the growing recognition of the importance of physics and the training which physics gives in industrial fields". His report will be much appreciated by readers who have not the time to devote to more detailed accounts.

\section{Electricity Costs and Factors}

IN a paper read to the Institution of Electrical Engineers on March 11, Mr. J. A. Sumner pointed out some of the modern factors which affect electricity costs and charges. He makes a brief comparison between rural and urban distribution and concludes that rural areas quickly become remunerative. $\mathrm{He}$ suggests that the expansion of demand must be preceded by a reduction of charges for domestic supply, and a halt should be called in the downward trend of charges for power. The alteration in charges must be accompanied by a greater unification of charges and tariffs, and this can only be achieved quickly by means of a single executive authority which would have the exclusive right to direct and initiate the unification of tariffs and charges. Prices for domestic supply are generally too high to permit an extensive use of electricity, and statisties show that reductions in price tend to follow an increased demand instead of preceding it. So far as the domestic consumer is concerned, for large modern undertakings the original Hopkinson definition, namely, that the fixed charge per quarter should be proportional to the greatest rate at which a consumer may ever use electricity, is no longer applicable. If we are to retain the two part system of charging for electricity, we must reconsider the basis to be adopted for charging. The correct kilowatt charge for each consumer depends upon the time of demand, the 'diversity' of the consumers' load and of the group of consumers with whom he is associated, the voltage of supply and many other factors. It looks as if it were a problem which would not admit in practice of even an approximate solution applicable to all cases.

\section{Cotton Growing Research}

AT a meeting of the Administrative Council of the Empire Cotton Growing Corporation held in Manchester on January 26, the director mentioned the extremely bad cotton season that had been experienced in Nyasaland. He said that information received by the Corporation indicated that the loss of crop has been caused to a large extent by insect pest damage, and if this is to be reduced effectively a close season for cotton of at least two months is a necessity. The Government is anxious to extend cotton growing on the Lilongwe Plateau. The Corporation's staff has pointed out, however, that the Plateau is at about the limit of altitude at which successful cotton-growing in Nyasaland is possible; it seems, therefore, that it would be wise to try cotton there on a small scale only, before any attempt is made at extensive production. A pest survey would also be needed as a preliminary in the adjacent area. The Director referred to the importance to the natives of Nyasaland of an economic crop as a means of restricting the present uncontrolled emigration of adult males into other countries in search of work, which is the cause of the breaking up of village life and much consequent poverty and distress.

THE report of the executive stated that over a large part of Africa insect pest damage is probably the limiting factor in cotton production. One insect, the jassid, has now been to a large extent controlled by the breeding of a resistant type of cotton by the Corporation's staff at the Experiment Station at Barberton in South Africa. This variety is now grown in many parts of Africa, including Rhodesia and Nyasaland, and in parts of Tanganyika and Uganda. The Corporation's staff have therefore been turning much of their attention to work on bollworms 
and stainers, and it is suggested that some increase in staff is necessary. The Director decided, however, that before he would feel justified in recommending the executive committee to sanction this, he needs to be assured that the work already being done is on the right lines, and that the methods by which the different problems are being attacked are those best calculated to lead to the possibility of devising some means of control of these pests. The executive committee accordingly invited Prof. J. W. Munro, professor of entomology at the Imperial College of Science and Technology, to make a tour of the experiment stations in South Africa, Rhodesia and Nyasaland, where the work is going on, and to advise the Corporation whether this work should be continued on the present lines or modified, and to report whether the prospects of success justify extension of the work, or its maintenance on the present, or on a reduced, scale.

\section{British Bird Sanctuaries}

ThE biannual report of the Watchers' Committee of the Royal Society for the Protection of Birds, issued privately, covers the 1935 and 1936 seasons at the Society's bird sanctuaries in thirteen English counties, three Welsh counties and four Scottish counties, and contains the scheme and appeal for the purchase of Dengemarsh, a stretch of shingle on the south coast of Kent that, with the adjoining sanctuaries of Walkers Outland and the Open Pits shingle, will form a continuous 1,281 acres sanctuary for terns, waders and winter visitors. The Durham (Teesmouth) sanctuary has also a scheme for the extension of watching throughout the year to protect winter visitors. The most extensive reports are made by the watchers in Lakeland, Kent, Orkney and Shetland. All the Scottish sanctuaries report 1936 as being far better than 1935. The Orkney sanctuary at Stenaday reports hen-harriers, which include an albino strain, shelduck and eiders are increasing and merlins and short-eared owls decreasing there: red-necked phalaropes are holding their own where nesting on north Ronaldshay and have a new nesting ground at Papa Westray. In the Shetland sanctuaries gannets, eider, terns, great skuas, arctic skuas, fulmars, starlings, puffins, guillemots, mallard and shags have increased but kittiwakes, razorbills (in parts) and the common gull (which no longer nests on Hermaness) have decreased. Disease has wiped out the house-sparrows from Mid Yell. Very detailed returns are made by the Dungeness and Dengemarsh watchers of Kent, this sanctuary in addition to its ternary being very rich in migrants which last year included the black redstart. Stone-curlews and redlegged partridge have also nested successfully there, but oil and oiled birds are still frequent shore troubles.

\section{The R.H.S. Lily Year-Book}

The Royal Horticultural Society's lily Year-Book for 1936 (London, from the Society's Office, Vincent Square, Westminster, S.W.1, 5s. paper, 6s. cloth, 1936) includes a number of contributions to a scientific understanding of lily culture. Dr. Fred Stoker has made a study of the contractile roots of these plants. $\mathrm{He}$ shows that members of the Eulirion section of the genus Lilium possess such structures. Much interesting information as to how contractile roots of daughter bulbils penetrate the root-plate of the mother bulb, is imparted, and the microscopic anatomy has been investigated. An attractive feature of the volume is a bibliography of more than 550 references to published works upon lilies. This has been compiled by the Abbé Souillet, and although it appears comprehensive, it does not claim to have included a large number of articles which have appeared in English periodicals from time to time. A paper by Dr. M. A. H. Tincker shows that a suitable soil temperature of $65^{\circ}-70^{\circ} \mathrm{F}$. is an important factor in the propagation of lilies from bulb scales. It is interesting to note that soil heating by electric cables or hot-water pipes is suggested as an aid to this method of propagation. Many other papers communicate knowledge upon geographical or horticultural aspects of lily growing, and an interesting note by Mr. P. Rosenheim announces the discovery of an early treatise on the lily, contained in a German encyclopaedia by Kruenitz and Floerke, dated 1800 .

\section{Soviet Medical Films}

According to the Soviet Union Year Book Press service, moving pictures are being used in the U.S.S.R. for the treatment of nervous and mental diseases. Prof. Sukharebsky, of the Yakovenko Psychiatric Hospital in Moscow, has obtained remarkable success by showing epileptic patients films depicting calm lakes, picturesque landscapes, etc. He has also obtained good results by the use of a film in which he hypnotizes alcoholic addicts. A plan for a series of 102 short medical films has recently been approved by the Film Committee appointed by the Commissar of Health. The series includes brain operations and diseases of the spinal cord and brain. Other films are designed to assist surgeons to carry out rapid field operations in time of war. A film entitled "A Sick and a Healthy Heart" will be made under the direction of the heart specialist Prof. Zelenin, and another will deal with the development of the child between the ages of one month and two years. The last of the series will be a film entitled "Twenty Years of Soviet Medicine".

\section{Early Man in Japan}

EVIDENCE of the presence of palæolithic man is reported from an island in southern Japan. The discovery, it is stated by Science Service (Washington, D.C.), was made by Prof. Shigeyasu Tokunaga, geologist of Waseda University, who while exploring the Island of Itoe in the Loochoo group, found numerous fossil bones of deer, which bore marks of having been worked by human hands. The deer from which the bones were derived has long been extinct, having died out in the neolithic age. Numerous teeth, antlers and bones of the same species of deer of the same age, which Prof. Tokunaga dates at anything from 30,000 to 70,000 years ago, 